\title{
Perspective
}

\section{Health-sector responses to address the impacts of climate change in Nepal}

\author{
Meghnath Dhimal',2, Mandira Lamichhane Dhimal2,3, Raja Ram Pote-Shrestha ${ }^{4}$, David A Groneberg ${ }^{2}$, Ulrich Kuch² \\ ${ }^{1}$ Nepal Health Research Council, Kathmandu, Nepal, ${ }^{2}$ Institute of Occupational, Social and Environmental Medicine, Goethe \\ University, Frankfurt am Main, Germany, ${ }^{3}$ Faculty of Social Sciences, Goethe University, Frankfurt am Main, Germany, ${ }^{4}$ World \\ Health Organization Country Office for Nepal, Kathmandu, Nepal
}

Correspondence to: Dr Meghnath Dhimal (meghdhimal@gmail.com)

Abstract
Nepal is highly vulnerable to global climate change, despite its negligible emission of global greenhouse
gases. The vulnerable climate-sensitive sectors identified in Nepal's National Adaptation Programme of Action
(NAPA) to Climate Change 2010 include agriculture, forestry, water, energy, public health, urbanization and
infrastructure, and climate-induced disasters. In addition, analyses carried out as part of the NAPA process
have indicated that the impacts of climate change in Nepal are not gender neutral. Vector-borne diseases,
diarrhoeal diseases including cholera, malnutrition, cardiorespiratory diseases, psychological stress, and
health effects and injuries related to extreme weather are major climate-sensitive health risks in the country.
In recent years, research has been done in Nepal in order to understand the changing epidemiology of
diseases and generate evidence for decision-making. Based on this evidence, the experience of programme
managers, and regular surveillance data, the Government of Nepal has mainstreamed issues related to
climate change in development plans, policies and programmes. In particular, the Government of Nepal has
addressed climate-sensitive health risks. In addition to the NAPA report, several policy documents have been
launched, including the Climate Change Policy 2011; the Nepal Health Sector Programme - Implementation
Plan II (NHSP-IP 2) 2010-2015; the National Health Policy 2014; the National Health Sector Strategy $2015-$
2020 and its implementation plan (2016-2021); and the Health National Adaptation Plan (H-NAP): climate
change and health strategy and action plan (2016-2020). However, the translation of these policies and plans
of action into tangible action on the ground is still in its infancy in Nepal. Despite this, the health sector's
response to addressing the impact of climate change in Nepal may be taken as a good example for other
low- and middle-income countries.

Keywords: adaptation plan, climate change, diarrhoeal disease, gender, public health, vector-borne disease

\section{Background}

There is a global consensus that the climate change we are experiencing worldwide is natural and anthropogenic but mainly accelerated by the anthropogenic emission of so-called greenhouse gases into the atmosphere.1,2 The published literature continues to focus mainly on the effects of climate change in high-income countries. The effects on the most vulnerable populations of low- and middle-income countries have been grossly underreported in the past, ${ }^{3}$ and that imbalance is improving only slowly. ${ }^{4}$ These low- and middle-income countries are historically least responsible for emissions of greenhouse gases but most vulnerable to the impacts of climate change, an imbalance that has been described as a "growing ethical crisis". ${ }^{5}$ The largest health risks are observed, and will continue to occur, in populations that are most affected by climate-sensitive diseases, such as vector-borne and waterborne diseases, and in those that are deprived of economic development. ${ }^{4}$ Thus, climate change disproportionately affects people with less power or those who are discriminated against because of factors such as their gender, ethnicity or socioeconomic status. ${ }^{6}$ Hence, poor people, members of minority groups, women, children, elderly people, people with chronic diseases and disabilities, those residing in areas with a high prevalence of climate-sensitive risks and diseases, and workers exposed to extreme heat or increased weather variability are the most vulnerable to the adverse impacts of climate change. ${ }^{6}$

Despite Nepal's very low contribution to global emissions of greenhouse gases $(0.027 \%),{ }^{7}$ it is one of the countries that is most vulnerable in the world to the impacts of climate change. In the Global Climate Risk Index, published by the nongovernmental organization Germanwatch, which is an analysis of the quantified impacts of extreme weather events, Nepal was the seventh-most affected country in 2014, with 1.90 deaths per 100000 inhabitants, losses of US\$ 143 million in purchasing power parity and $0.21 \%$ loss per unit of gross domestic product. ${ }^{8}$ Nepal's particular vulnerability to climate change is a result of its geographical position in the "third pole" of this planet (the Himalayan mountains and Tibetan 
plateau), complex topography with steep mountain slopes and many rivers, and low socioeconomic status of the people, who largely depend on climate-sensitive sectors, such as agriculture. ${ }^{9}$

Several studies have shown a trend of increasing temperatures in Nepal in recent decades, with higher warming rates in the hill and mountain regions than in the lowlands (Siwalik and Terai). ${ }^{10-13}$ Changes in precipitation do not show such distinct trends in Nepal. However, there have been changes in the frequency and severity of extreme weather events, such as heavy rainfall, droughts, heat waves and cold waves. ${ }^{13,14}$ The combined effects of increased temperature and diminished snowfall, followed by the rapid retreat of the majority of glaciers, have resulted in a depletion of the amount of water available for drinking, livestock and irrigation in the hill and mountain regions of Nepal. ${ }^{12,15,16}$

The Climate and Health Country Profile Project, a joint collaboration between the World Health Organization (WHO) and the Secretariat of the United Nations Framework Convention on Climate Change, compared the effects of the highest and lowest of the emissions pathways defined by the Intergovernmental Panel on Climate Change with a situation in which the extent of climate disruption is limited for each country. ${ }^{17}$ For Nepal, the project estimated that, under the highemissions scenario, the mean annual temperature is projected to rise by about $6{ }^{\circ} \mathrm{C}$; the number of days with very heavy precipitation ( $20 \mathrm{~mm}$ or more) could increase by about 6 days, leading to a higher risk of floods; and the longest dry spell could increase by about 14 days, from an average of about 80-90 days, with large year-to-year variability from 1990 to $2100 .{ }^{18}$ Hence, climate change and climate-induced extreme events will continue to accelerate the loss of lives and property and increase the burden of diseases in Nepal, unless timely corrective actions are taken. The aim of this paper is to provide a perspective on climate-sensitive health risks, vulnerability, research evidence and health-sector responses to address the health risks of climate change in Nepal.

\section{Current climate-sensitive health risks in Nepal}

The Government of Nepal has identified public health as one of the sectors that is most vulnerable to the negative effects of climate change. The potential health impacts of climate change in Nepal include vector-borne, waterborne, airborne and foodborne diseases, nutrition-related diseases, injuries and mental illnesses. ${ }^{3,4,19}$ Climate change impacts directly on human health and indirectly via its effects on diseasetransmitting agents. Based on global evidence and scientific consensus, Nepal will observe the changes summarized in Box 1 if climate change continues as projected..$^{20,21}$

In order to avoid or prevent these health risks of climate change in the near and distant future, appropriate strategies are essential for early planning and strengthening of the country's health system. The inclusion of the health sector in adaptation planning can yield synergies in actions to protect population health and result in the policies and programmes of other sectors contributing to health co-benefits. ${ }^{20}$ Hence, multisectoral collaboration and coordination is of utmost importance for addressing the health risks of climate change in Nepal.
Box 1. Projected effects on Nepal of unabated climate change

- Greater risk of injury, disease and death, owing to moreintense heat waves, cold waves and forest fires

- Increased risk of undernutrition, resulting from diminished food production in resource-poor regions

- More negative health consequences of lost work capacity and reduced labour productivity in vulnerable populations

- Increased risk of vector-borne, waterborne and foodborne diseases, especially in mountain areas, and leading to perennial occurrence in the lowlands

- Increase in cardiorespiratory diseases, owing to higher ambient air pollution and haze in urban areas, resulting from climate change

- Increase in mental health problems, owing to extreme climatic events such as droughts, floods and landslides

- Modest reductions in cold-related mortality and morbidity in the highlands, owing to fewer cold extremes

- Increased morbidity and mortality related to cold waves in the southern Terai lowlands

- Reduced disease-transmission capacity of vector insects in the Terai, owing to higher temperatures exceeding their thermal thresholds

\section{Vulnerable populations and gender}

The vulnerability of a population to a health risk related to climate depends on exposure, the availability of local resources, the effectiveness of governance and public institutions, the quality of public health infrastructure, and access to relevant local information on extreme weather threats and early-warning systems. ${ }^{4}$ Although all populations are vulnerable to the adverse health impacts of climate change, those living in flood-prone areas, mountain regions, water-stressed regions and densely populated urban areas are exposed to the greatest risks. Analyses carried out in Nepal have shown that men and women differ with respect to climate vulnerability and impacts, owing to sociocultural factors, differential access to and control over resources, and institutional arrangements. ${ }^{9}$ For example, the depletion of water resources causes particularly serious problems to women, especially with respect to sanitation, health and safety. Limited access to water resources for women, girls and children increases their workload and walking distances, which can contribute to adverse health effects, such as on personal hygiene or aspects of reproductive health, including uterine prolapse. ${ }^{22}$ Similarly, other health impacts of climate change, such as epidemics, increase the workload for women, since women in Nepal are culturally responsible for taking care of family members who are ill, children and elderly individuals. Furthermore, there are concerns that the impacts of climate change in Nepal are contributing to outbound migration of men seeking employment overseas, thereby increasing the health impacts of climate change on the women left behind mainly in the rural areas. Hence, continuing climate change may exacerbate gender differences in health outcomes in Nepal. 


\section{Evidence on the health impacts of climate change in Nepal}

There are limited etiological studies on the health impacts of climate change in Nepal. Challenges to conducting such research in mountainous low- or middle-income countries include a lack of trained human resources, financial resources, long-term data and information, and suitable methods that are applicable to the local context. ${ }^{23}$ Despite these challenges, a number of research studies focusing on the effects of climate factors on vector-borne and waterborne diseases have been carried out in Nepal.

\section{Vector-borne diseases}

Nepal is endemic for seven major vector-borne diseases, namely malaria, lymphatic filariasis, Japanese encephalitis, visceral leishmaniasis, dengue, chikungunya and scrub typhus. A systematic review of the literature found evidence for a pronounced warming in the highlands, an expansion of autochthonous cases of vector-borne diseases to previously non-endemic highland areas including mountain regions, and significant relationships between climatic variables and vectorborne diseases and/or their vectors. ${ }^{24}$ Despite a significant decline in the number of cases of malaria in Nepal over the last decade, the distributions of malaria cases and malaria mosquitoes (Anopheles spp.) have expanded in hill and mountain regions that had previously been considered nonendemic. ${ }^{25-27} \mathrm{~A}$ study conducted in two districts that are highly endemic for malaria showed that a $1{ }^{\circ} \mathrm{C}$ increase in minimum and mean temperatures increased the incidence of malaria by $27 \%$ and $25 \%$, respectively. ${ }^{28}$

The first reported case of dengue virus infection in Nepal was a Japanese volunteer in 2004, and the first local transmission of dengue virus in Nepal was confirmed during a 2006 outbreak in urban areas of the lowlands; dengue fever has subsequently extended its geographical range in the Terai and hill regions of Nepal. ${ }^{24,29}$ Similarly, cases of chikungunya fever have been reported from different districts of Nepal, including the hill regions, with a first report of confirmed indigenous cases in 2013. ${ }^{30,31}$ The mosquito vectors of these two viral diseases (and of Zika virus), Aedes aegypti and Aedes albopictus, have established populations up to at least $2000 \mathrm{~m}$ above mean sea level in Nepal. ${ }^{27,32}$ Significant effects of the climatic factors of temperature, rainfall and relative humidity on the abundance of these vector species has been reported from central Nepal. ${ }^{32,33}$ Although infections with Japanese encephalitis virus have been reported from 24 districts of the Terai region only in the past, Japanese encephalitis virus has recently been shown to have extended its distribution to hill and mountain regions of Nepal. ${ }^{24,34}$ Its principal vectors, Culex tritaeniorhynchus mosquitoes, have established populations at least $2000 \mathrm{~m}$ above mean sea level in Nepal. The spatiotemporal distribution of lymphatic filariasis caused by Wuchereria bancrofti is now also endemic in additional hill and mountain regions of Nepal. ${ }^{24}$ The principal vectors of lymphatic filariasis in Nepal, Culex quinquefasciatus mosquitoes, have established populations up to at least $2100 \mathrm{~m}$ above mean sea level in Nepal (the highest sampled altitude in Nepal in that study). ${ }^{33}$ Moreover, significant effects of the climatic factors of temperature and relative humidity on the mean abundance of C. quinquefasciatus per trap have been reported, indicating likely effects of climate change on the transmission of lymphatic filariasis. ${ }^{32}$ Spatio-temporal analysis of visceral leishmaniasis in Nepal shows an expansion of autochthonous cases and of the principal vector (Phlebotomus argentipes sand flies) towards the hill and mountain regions over the last decade. ${ }^{24}$ A recent outbreak investigation confirmed local transmission of visceral leishmaniasis in hill districts of eastern Nepal. ${ }^{35} \mathrm{~A}$ positive association of cases of visceral leishmaniasis with the climatic factors of temperature and rainfall has been observed, with reports of disease outbreaks 2-3 months after heavy rainfall in Nepal. ${ }^{25}$

Both climatic and non-climatic factors have played a significant role in epidemics and the control of vector-borne diseases, but the net effects depend on socioeconomic development and the capacity of the health system to control vectors and provide timely diagnosis, management and effective treatment of affected individuals. ${ }^{36}$ Hence, climate change is expected to increase the risk of epidemics of vectorborne diseases in highland regions of Nepal that had previously been considered non-endemic, if other non-climatic drivers of vector-borne diseases remain constant.

\section{Waterborne diseases}

Although case-fatality rates of diarrhoeal diseases are declining in Nepal, the incidence among children under 5 years of age has been increasing in the last decade. ${ }^{37}$ Frequent outbreaks of diarrhoeal diseases, including cholera, have been reported from different districts of Nepal in recent years. ${ }^{37} \mathrm{An}$ analysis of data on temperature and diarrhoea from July 2002 to June 2014 estimated that, for a $1{ }^{\circ} \mathrm{C}$ increase in ambient temperature, the incidence of diarrhoeal diseases in Nepal rose by $4.39 \% .^{38}$ The same study also estimated that, for a $1 \mathrm{~cm}$ increase in annual rainfall, the incidence of diarrhoeal diseases rose by $0.28 \%$. In the same time period, coverage of water supply and sanitation in Nepal, as well as the economic status of the population, has improved, and the community-based integrated management of childhood illness programme was scaled up. ${ }^{37}$ Nevertheless, the United Nations Children's Fund Nepal Multiple Indicator Cluster Survey for 2014 found $82.2 \%$ of samples of household drinking water and $71.1 \%$ of samples of source water were contaminated with Escherichia coli bacteria (risk level $\geq 1$ colony-forming units [cfu]/100 mL). ${ }^{39}$ Hence, climate change and climate variability may be contributing to increasing risks for diarrhoeal diseases.

\section{Policies and programmes: work to date}

The health sector has recently started to mainstream climate change into health-sector plans, policies and programmes in Nepal. The Nepal Health Research Council (NHRC), with the support of the WHO Country Office for Nepal, identified and prioritized climate change as one of its research areas in 2006. Then, NHRC and the WHO Country Office for Nepal convened a national workshop on climate change and human health in December 2007. This was possibly the first healthsector workshop on climate change in Nepal and it sensitized more than 80 participants, including government programme managers, policy-makers, academics, researchers, members of civil society and journalists. ${ }^{40}$ The workshop recommended generating country-level evidence on climate change and health through research, and raising awareness on this 
Dhimal et al.: Health-sector responses to the impacts of climate change in Nepal

emerging issue at various levels, from the public in general to policy-makers. Thereafter, a number of studies on these topics were carried out in Nepal, with major support from WHO.

\section{National Adaptation Programme of Action (NAPA) to Climate Change, 2010}

The National Adaptation Programme of Action (NAPA) to Climate Change of Nepal identified health as one of the sectors that were most vulnerable to climate change. ${ }^{9}$ A Public Health Thematic Working Group was formed under the leadership of the Ministry of Health and contributed to identifying the adaptation needs of the health sector. The following are the prioritized activities for public health adaptation to climate change:

- reducing public health impacts of climate change through evidence-based research and piloting;

- empowering communities through education for responding to the adverse effects of climate change in public health;

- investing in disease-outbreak and emergency response;

- scaling up programmes on vector-borne, waterborne and foodborne diseases and disasters;

- strengthening forecasting/early-warning and surveillance systems for climate change and health. ${ }^{9}$

\section{Nepal Health Sector Programme - Implementation Plan II 2010-2015}

The Nepal Health Sector Programme - Implementation Plan II (NHSP-IP 2) 2010-2015 was the first health-sector plan that included a component on climate change. ${ }^{41}$ This plan had the objective to improve the health system to achieve universal coverage of essential health services, including control of communicable disease. The plan added sanitation and hygiene for communities as one of the health-promotion activities, and environmental health (water, air quality, sanitation, hygiene, waste disposal) as one of the components of essential health services for piloting and scaling up through intersectoral partnership. This plan also included establishment of a knowledge network with academia and practitioners on climate change, and a public health response team for climate change.

\section{Climate Change Policy 2011}

The Climate Change Policy 2011 aimed to form a sectorwide working group and integrate policy on climate change in the sector policies. ${ }^{42}$ After the introduction of this policy, sectoral thematic groups were formed and climate change units have been established in various ministries, including the Ministry of Health. In some ministries, existing units such as policy and planning are designated as focal units for climate change. The policy has emphasized the implementation of preparedness programmes for disasters and epidemics; regular implementation of public-awareness and capacitybuilding programmes; preparation and regular updating of appropriate climate-forecasting models for Nepal, based on regional climate models; and allocation of at least $80 \%$ of available adaptation funds to programmes at the community level related to climate change. Many provisions of this policy are reflected in health-sector policies and plans, such as the National Health Policy $2014^{43}$ and the Nepal Health Sector Strategy Implementation Plan (2016-2021). ${ }^{44}$
National health policy, strategy and implementation plan The main objective of the National Health Policy 2014 is universal coverage of health services for all. ${ }^{43}$ The policy has one objective to gradually mainstream health into all policies, by further strengthening collaboration with stakeholders in health across all sectors. In order to achieve this objective of health in all policies, ${ }^{45}$ the following strategies have been adopted:

- the health agenda will be included in all concerned policies;

- for the overall management of the negative effects of climate change on health, a multisectoral action plan will be developed in collaboration with all stakeholders, with proper utilization of national networks and mechanisms or opportunities;

- the action plan will be prepared and implemented in such a way that there will be multisectoral coordination on various aspects, such as safe drinking water, sanitation, energy, food security, climate, environment, education, accommodation, and infrastructure development (including roads that affect access to health services).

Guided by the National Health Policy $2014,{ }^{43}$ the Nepal Health Sector Strategy 2015-2020 prioritizes multisectoral collaboration to address the social determinants of health. ${ }^{44}$ The strategy articulates the nation's commitment towards achieving universal health coverage and emphasizes the need to establish a multisectoral response to climate change.

Key interventions identified in the Nepal Health Sector Strategy Implementation Plan 2016-2021 are:46 (i) generation of evidence on the impact of climate change on human health; (ii) implementation of the NAPA to Climate Change with respect to planning and preparedness for disasters induced by climate change; (iii) monitoring changes in vector- and disease-distribution patterns; (iv) expansion of water-quality surveillance; and ( $v$ ) collaboration with other sectors to enforce standards for air, water and food quality.

Health National Adaptation Plan (H-NAP): climate change and health strategy and action plan (2016-2020)

The Ministry of Health of Nepal, with support from the WHO Country Office for Nepal, carried out a vulnerability and adaptation assessment of the health sector. Based on the results of this assessment and other research evidence, the Health National Adaptation Plan (H-NAP): climate change and health strategy and action plan was developed and was approved in 2016. The H-NAP has a vision to develop climateresilient health systems to protect human health from climate change in Nepal. ${ }^{20}$ This plan aims to develop national strategies on climate change and health, with an adequate focus on the health sector and intersectoral collaboration to protect health from the adverse effects of climate change. Furthermore, it aims to ensure that health issues are considered in the ongoing formulation process of the National Adaptation Plan, ${ }^{47}$ so that policies and programmes in other sectors contribute to health co-benefits.

As a part of institutional reform, a dedicated Disease Control, Climate Change and Environmental Health section was established in the Ministry of Health in 2016, which works as a focal point for environmental health and climate change in Nepal. Several research projects on climate change and health have been carried out by the NHRC, academic institutions and 
Dhimal et al.: Health-sector responses to the impacts of climate change in Nepal

individual researchers. Awareness-raising programmes on climate change and health are carried out by the National Health Education, Information and Communication Centre, through district public health offices. A component on climate change is incorporated in regular induction training sessions of the National Health Training Centre. The Epidemiology and Diseases Control Division (EDCD) of the Department of Health Services is working on control of vector-borne disease; strengthening early-warning and reporting systems; surveillance of water quality; and disaster risk management. Based on research evidence and surveillance data, the EDCD has, for example, scaled up the programme for control of visceral leishmaniasis in hill districts of Nepal. ${ }^{37}$ The WHO Country Office for Nepal has been supporting the Ministry of Health to build a climateresilient health system. A multidisciplinary thematic working group on public health and water, sanitation and hygiene has been formed under the leadership of the Ministry of Health and is working to align health-specific components in the National Adaptation Plan formulation process. ${ }^{47}$ In conclusion, Nepal is making good progress towards mainstreaming climate change in its plans, strategies and policies, although enforcement of these provisions and translation to tangible action on the ground is still in its infancy.

\section{Policies and programmes: next steps}

There is an urgent need to conduct more research studies on vector-borne and waterborne diseases and other climatesensitive diseases and risks, including noncommunicable ones, to inform evidence-based health-adaptation planning and programming for climate change in Nepal. This requires strengthening of data recording and reporting in the disease surveillance and health management information systems. Multisectoral preparedness plans are needed, to address the impacts from climate-related extremes such as heat waves, cold waves, droughts, floods, fire and storms. As health is directly and indirectly affected by climate change via various pathways, there should be a focus on health in national adaptation plans for the medium- and long-term adaptation needs of all sectors, including agriculture, energy, water, forestry and infrastructure. Enhancement of awareness is required, from grass-roots to policy-maker levels, and medical and health sciences curricula should be updated where content on climate change and health is missing or minimal. The health-sector policies and planning should focus on developing climate-resilient health systems. ${ }^{48}$ For this, climate change should be considered as an important determinant of health within each of the six core components or "building blocks" of the WHO framework for health systems: (i) service delivery; (ii) health workforce; (iii) health information systems; (iv) access to essential medical products, vaccines and technologies; (v) financing; and (vi) leadership/governance. ${ }^{49}$ Finally, existing policies, strategies and plans on climate change and health should be prioritized for implementation now, rather than waiting for more evidence and policies.

Source of support: None.

Conflict of interest: None declared.

Authorship: MD developed the structure and prepared the draft of the manuscript, MLD contributed to writing the manuscript, RRP-S contributed to writing and revising the manuscript, DAG contributed to critically reviewing the manuscript and UK contributed to critically reviewing and editing the manuscript.

How to cite this paper: Dhimal M, Dhimal ML, Pote-Shrestha RR, Groneberg DA, Kuch U. Health-sector responses to address the impacts of climate change in Nepal. WHO South-East Asia J Public Health. 2017;6(2):9-14.

\section{References}

1. Stocker TF, Qin D, Plattner G-K, Tignor MMB, Allen SK, Boschung $J$ et al., editors. IPCC. Climate change 2013. The physical science basis. Working group I contribution to the fifth assessment report of the Intergovernmental Panel on Climate Change. Cambridge and New York: Cambridge University Press; 2013 (https://www.ipcc.ch/ pdf/assessment-report/ar5/wg1/WG1AR5 Frontmatter_FINAL.pdf, accessed 6 June 2017).

2. Solomon S, Qin D, Manning M, Chen Z, Marquis M, Averyt KB et al., editors. Climate change 2007. The physical science basis. Working group I contribution to the fourth assessment report of the Intergovernmental Panel on Climate Change. Cambridge and New York: Cambridge University Press; 2007 (https://www.ipcc.ch/pdf/ assessment-report/ar4/wg1/ar4 wg1 full report.pdf, accessed 6 June 2017).

3. Confalonieri U, Menne B, Akhtar R, Ebi KL, Hauengue M, Kovats RS et al. Human health In: Parry ML, Canziani OF, Palutikof JP, van der Linden PJ, Hanson CE, editors. Climate change 2007. Impacts, adaptation and vulnerability. Contribution of Working Group II to the fourth assessment report of the Intergovernmental Panel on Climate Change. Cambridge and New York: Cambridge University Press; 2007:391-431 (https://www.ipcc.ch/pdf/assessment-report/ar4/wg2/ar4wg2-chapter8.pdf, accessed 6 June 2017).

4. Smith KR, Woodward A, Campbell-Lendrum C, Chadee DD, Honda Y, Liu Q et al. Human health: impacts, adaptation, and co-benefits. In: Field CB, Barros VR, Dokken DJ, Mach KJ, Mastrandrea MD, Bilir TE et al., editors. Climate change 2014: impacts, adaptation, and vulnerability. Part A: Global and sectoral aspects. Contribution of Working Group II to the fifth assessment report of the Intergovernmental Panel on Climate Change. Cambridge and New York: Cambridge University Press; 2014:709-54 (http://www.ipcc. ch/pdf/assessment-report/ar5/wg2/WGIIAR5-Chap11 FINAL.pdf, accessed 27 June 2017).

5. Patz J, Gibbs H, Foley J, Rogers J, Smith K. Climate change and global health: quantifying a growing ethical crisis. EcoHealth. 2007;4(4):397-405. doi:10.1007/s10393-007-0141-1.

6. Levy BS, Patz JA. Climate change, human rights, and social justice. Ann Glob Health. 2015;81(3):310-22. doi:10.1016/j.aogh.2015.08.008.

7. Nepal second national communication to United Nations Framework Convention to Climate Change. Kathmandu: Government of Nepal, Ministry of Science, Technology and Environment; 2014 (http://unfccc. int/resource/docs/natc/nplnc2.pdf, accessed 6 June 2017).

8. Kreft S, Eckstein D, Dorsch L, Fischer L. Global Climate Risk Index 2016. Who suffers most from extreme weather events? Weatherrelated loss events in 2014 and 1996 to 2014. Bonn: Germanwatch; 2015 (https://germanwatch.org/fr/download/13503.pdf, accessed 6 June 2017).

9. National Adaptation Programme of Action (NAPA) to Climate Change Kathmandu: Government of Nepal, Ministry of Environment; 2010 (http://unfccc.int/resource/docs/napa/npl01.pdf, accessed 6 June 2017)

10. Shrestha AB, Wake CP, Mayewski PA, Dibb JE. Maximum temperature trends in the Himalaya and its vicinity: an analysis based on temperature records from Nepal for the period 1971-94. J Climate. 1999;12(9):2775-86. doi:10.1175/1520-0442.

11. Qi W, Zhang YL, Gao JG, Yang XC, Liu LS, Khanal NR. Climate change on the southern slope of Mt. Qomolangma (Everest) Region in Nepal since 1971. J Geogr Sci. 2013;23(4):595-611. doi:10.1007/ s11442-013-1031-9.

12. Shrestha $A B$, Aryal R. Climate change in Nepal and its impact on Himalayan glaciers. Reg Environ Change. 2011;11(Suppl. 1):S65-S77. doi:10.1007/s10113-010-0174-9.

13. Baidya SK, Shrestha ML, Sheikh MM. Trends in daily climatic extremes of temperature and precipitation in Nepal. J Hydrol Meteorol. 2008;5(1):38-51. 
14. Shrestha AB, Bajracharya SR, Sharma AR, Duo C, Kulkarni A. Observed trends and changes in daily temperature and precipitation extremes over the Koshi river basin 1975-2010. Int J Climatol. 2017;37(2):1066-83. doi:10.1002/joc.4761.

15. Aryal A, Brunton D, Raubenheimer D. Impact of climate change on human-wildlife-ecosystem interactions in the Trans-Himalaya region of Nepal. Theor Appl Climatol. 2014;115(3-4):517-29. doi:10.1007/ s00704-013-0902-4.

16. Chaudhary P, Bawa KS. Local perceptions of climate change validated by scientific evidence in the Himalayas. Biol Lett. 2011;7(5):767-70. doi:10.1098/rsbl.2011.0269.

17. World Health Organization, United Nations Framework Convention on Climate Change. Climate and health country profiles -2015 . A global overview. Geneva: World Health Organization; 2015 (http://apps.who. int/iris/bitstream/10665/208855/1/WHO FWC PHE EPE 15.01 eng. pdf?ua=1, accessed 6 July 2017).

18. World Health Organization, United Nations Framework Convention on Climate Change. Climate and health country profile - 2015, Nepal. Geneva: World Health Organization; 2015 (http://www.searo.who.int/ entity/water sanitation/nep c h profile.pdf?ua=1, accessed 6 June 2017).

19. Dhimal M, Bhusal C. Impacts of climate change on human health and adaptation strategies for Nepal. J Nepal Health Res Counc. 2009;7(2):140-1. doi:10.3126/jnhrc.v7i2.3025.

20. Health National Adaptation Plan (H-NAP): climate change and health strategy and action plan (2016-2020). Kathmandu: Government of Nepal, Ministry of Health; 2016.

21. Woodward A, Smith KR, Campbell-Lendrum D, Chadee DD, Honda Y, Liu Q et al. Climate change and health: on the latest IPCC report. Lancet. 2014;383(9924):1185-9. doi:10.1016/S0140-6736(14)60576-6.

22. Dhimal ML. Gender differentiated health impacts of environmental and climate change in Nepal. In: Pradhananga S, Panthi J, Bhattarai D, editors. Proceedings of International Conference on Climate Change Innovation and Resilience for Sustainable Livelihood, 12-14 January 2015, Kathmandu, Nepal. Kathmandu: Small Earth Nepal; 2015:96100 (https://smallearthnepal.files.wordpress.com/2016/12/conferenceproceedngs-climdev15.pdf, accessed 6 June 2017).

23. Dhimal M. Climate change and health: research challenges in vulnerable mountainous countries like Nepal. In: Climate change and health: research challenges for vulnerable populations. Geneva: Global Forum for Health Research; 2008:66-9 (http://announcementsfiles. cohred.org/gfhr_pub/assoc/s14887e/s14887e.pdf, accessed 6 June 2017).

24. Dhimal M, Ahrens B, Kuch U. Climate change and spatiotemporal distributions of vector-borne diseases in Nepal - a systematic synthesis of literature. PLoS One. 2015;10(6):e0129869. doi:10.1371/journal. pone.0129869.

25. Dahal S. Climatic determinants of malaria and kala-azar in Nepal. Regional Health Forum. 2008;12(1):33-7.

26. Dhimal M, Ahrens B, Kuch U. Malaria control in Nepal 1963-2012: challenges on the path towards elimination. Malar J. 2014;13:241. doi:10.1186/1475-2875-13-241.

27. Dhimal M, Ahrens B, Kuch U. Species composition, seasonal occurrence, habitat preference and altitudinal distribution of malaria and other disease vectors in eastern Nepal. Parasit Vectors. 2014;7:540. doi:10.1186/s13071-014-0540-4.

28. Dhimal M, O'Hara RB, Karki R, Thakur GD, Kuch U, Ahrens B. Spatiotemporal distribution of malaria and its association with climatic factors and vector-control interventions in two high-risk districts of Nepal. Malar J. 2014;13:457. doi:10.1186/1475-2875-13-457.

29. Acharya BK, Cao C, Lakes T, Chen W, Naeem S. Spatiotemporal analysis of dengue fever in Nepal from 2010 to 2014. BMC Public Health. 2016;16(1):849. doi:10.1186/s12889-016-3432-z.

30. Pun SB, Bastola A, Shah R. First report of Chikungunya virus infection in Nepal. J Infect Dev Ctries. 2014;8(6):790-2. doi:10.3855/jidc.3701.

31. Pandey BD, Neupane B, Pandey K, Tun MM, Morita K. Detection of Chikungunya virus in Nepal. Am J Trop Med Hyg. 2015;93(4):697-700. doi:10.4269/ajtmh.15-0092.

32. Dhimal M, Gautam I, Joshi HD, O'Hara RB, Ahrens B, Kuch U. Risk factors for the presence of chikungunya and dengue vectors (Aedes aegypti and Aedes albopictus), their altitudinal distribution and climatic determinants of their abundance in central Nepal. PLoS Negl Trop Dis. 2015;9(3):e0003545. doi:10.1371/journal.pntd.0003545.

33. Dhimal M, Gautam I, Kress A, Muller R, Kuch U. Spatio-temporal distribution of dengue and lymphatic filariasis vectors along an altitudinal transect in central Nepal. PLoS Negl Trop Dis. 2014;8(7):e3035. doi:10.1371/journal.pntd.0003035.

34. Baylis M, Barker CM, Caminade C, Joshi BR, Pant GR, Rayamaihi A et al. Emergence or improved detection of Japanese encephalitis virus in the Himalayan highlands? Trans R Soc Trop Med Hyg. 2016;110(4):209-11. doi:10.1093/trstmh/trw012.

35. Ostyn B, Uranw S, Bhattarai NR, Das ML, Rai K, Tersago K et al. Transmission of Leishmania donovani in the hills of Eastern Nepal, an outbreak investigation in Okhaldhunga and Bhojpur districts. PLoS Negl Trop Dis. 2015;9(8):e0003966. doi:10.1371/journal.pntd.0003966.

36. Dhimal M. Effects of climatic and non-climatic factors on the spatiotemporal distributions of vector-borne diseases in Nepal. Dissertation. Frankfurt am Main: Goethe University; 2015 (http://d-nb. info/1069517070/04, accessed 6 June 2017).

37. Department of Health Services annual report 2071/72 (2014/2015). Kathmandu: Government of Nepal, Department of Health Services, Management Division; 2016 (http://dohs.gov.np/wp-content/ uploads/2016/06/Annual Report FY 2071 72.pdf, accessed 6 June 2017)

38. Dhimal M, Karki KB, Aryal KK, Shrestha SL, Pradhan B, Nepal S et al. Final report on assessment of effects of climate factors on diarrheal diseases at national and sub-national levels in Nepal. Kathmandu: Nepal Health Research Council and Word Health Organization Country Office for Nepal; 2016.

39. Nepal. Monitoring the situation of children and women. Multiple Indicator Cluster Survey 2014. Final report. Kathmandu: Central Bureau of Statistics and UNICEF Nepal; 2015 (http://unicef.org.np/ uploads/files/597341286609672028-final-report-nmics-2014-english. pdf, accessed 6 June 2017).

40. Proceeding report of National Workshop on Climate Change and Human Health: potential impact, vulnerability and adaptation in Nepal. Kathmandu: Nepal Health Research Council; 2007 (nhrc.org.np/files/ download/6b23b3ceb2414f3, accessed 6 June 2017).

41. Nepal Health Sector Programme - Implementation Plan II (NHSP-IP 2) 2010-2015. Kathmandu: Government of Nepal Ministry of Health and Population; 2010 (http://www.nationalplanningcycles.org/sites/default/ files/country docs/Nepal/nhp_nepal.pdf, accessed 6 June 2017).

42. Climate Change Policy 2011. Kathmandu: Government of Nepal Ministry of the Environment; 2011 (http://www.climatenepal.org.np/ main/? $p=$ research\&sp=onlinelibrary\&opt=detail\&id $=419$, accessed 6 June 2017).

43. National Health Policy 2014. Kathmandu: Government of Nepal Ministry of Health; 2014 (http://nhsp.org.np/national-healthpolicy-2014-3/, accessed 6 June 2014).

44. Nepal Health Sector Strategy 2015-2020. Government of Nepal Ministry of Health and Population; 2015 (http://nepalphysio.org.np/ wp-content/uploads/2017/04/NHSS-English-Book-Inside-final.pdf, accessed 6 June 2017).

45. Kickbusch I, Buckett K. Implementing health in all policies: Adelaide 2010. Adelaide: Department of Health, Government of South Australia. 2010 (http://www.who.int/sdhconference/resources/ implementinghiapadel-sahealth-100622.pdf, accessed 6 June 2017).

46. Nepal Health Sector Strategy Implementation Plan 2016-2021. Kathmandu: Government of Nepal Ministry of Health; 2017 (http:// nhsp.org.np/wp-content/uploads/formidable/7/NHSS implementation plan 20162021 february2017.pdf, accessed 6 June 2017).

47. Government of Nepal, Ministry of Population and Environment. National Adaptation Plan formulation process (http://napnepal.gov.np/ publication, accessed 6 July 2017).

48. Operation framework for building climate resilient health systems. Geneva: World Health Organization; 2015 (http://apps.who.int/iris/ bitstream/10665/189951/1/9789241565073 eng.pdf?ua=1, accessed 6 July 2017).

49. Everybody business. Strengthening health systems to improve health outcomes: WHO's framework for action. Geneva: World Health Organization; 2007 (http://www.who.int/healthsystems/strategy/ everybodys business.pdf, accessed 27 June 2017). 